\title{
Cultivo de gránulo de kéfir en zumo de uvas tintas
}

\section{Kefir culture pellet red grape juice}

\author{
Santos Pedraza Guevara \\ Universidad de Vigo - España \\ Universidad Nacional Toribio Rodríguez de Mendoza de Amazonas - Perú
}

DOI: https://doi.org/10.33017/RevECIPeru2015.0006/

\section{Resumen}

Este estudio forma parte de investigaciones que desarrollan en el área de Bromatología, Dpto. de Química Analítica y Alimentaria, Universidad de Vigo Campus Ourense, España; cuyo objetivo final es producir bebidas fermentadas con propiedades probióticas con gránulos de kéfir en zumo de uvas tintas y blancas con ello se estaría valorizando uvas no vinificables con escaso valor comercial o consumo directo. Y obteniendo bebidas que combine efectos saludables de uva tinta fundamentalmente polifenoles con carácter antioxidante y beneficios funcionales del kéfir. Se estudió las cinéticas de principales variables del proceso fermentativo, se analizó el efecto del cambio de sustrato sobre la fermentación y poblaciones microbianas del kéfir. El procedimiento se llevó a cabo de la siguiente manera: se activaron el gránulo, se llevó a cabo una serie de 4 cultivos sucesivos. En cada uno se incubó el gránulo en zumo de uva tinta no estéril durante $24 \mathrm{~h}$. Se separó el gránulo y se sustituyó zumo fermentado por zumo fresco. A las 12 horas de incubación y en el zumo fermentado tras $24 \mathrm{~h}$ se tomaron muestras, se centrifugaron para separar biomasa a partir de la cual se determinó la concentración de células libres y las UFC de cada uno de los 3 grandes grupos microbianos bacterias ácido lácticas, acéticas y levaduras, y en los sobrenadantes se analizaron pH, azúcares y metabolitos mediante HPLC. Adicionalmente se tomaron muestras al inicio y final de cada fermentación para determinar conteos BLA, BAC y LEV. De acuerdo a los resultados obtenidos, parece lógico utilizar el producto fermentado obtenido para una doble finalidad. La bebida obtenida por fermentación de zumo de uvas tintas con gránulos de kéfir, podría ser utilizada como una nueva bebida alcohólica por su elevado contenido en etanol ( $\sim 33 \mathrm{~g} / \mathrm{L})$, previa separación de las células. Las células probióticas obtenidas, con alta viabilidad podrían ser utilizadas para producir un suplemento alimenticio, por los potenciales beneficios, que su uso podría producir sobre la salud de los consumidores del producto. Las concentraciones de biomasa libre obtenidas en el zumo durante los dos primeros pases, oscilan entre 1 y $2 \mathrm{~g} / \mathrm{L}$, pero en el tercer pase, se obtiene un valor máximo en torno a los $6 \mathrm{~g} / \mathrm{L}$. Este repunte en la producción de biomasa libre en el tercer pase, se corresponde también con el incremento del consumo de azúcares (glucosa y fructosa) a partir del tercer pase (subcultivo), posiblemente porque en esta etapa ya los gránulos de kéfir estaban adaptados a la composición del nuevo medio de fermentación con respecto al medio de activación. En cuanto a la formación de productos, llama poderosamente la atención, en comparación con los cultivos en suero de leche, las elevadas producciones de etanol que superan en 4 veces, las obtenidas en suero de leche y el consumo completo del ácido láctico del medio de fermentación, la total ausencia de ácido acético, además de la producción de cantidades apreciables de glicerol desde $2 \mathrm{~g} / \mathrm{L}$ en el primer pase hasta aproximadamente $6 \mathrm{~g} / \mathrm{L}$, en el cuarto pase. Todo ello sugiere una mayor actividad de la población levaduriforme con respecto a las poblaciones de bacterias lácticas y acéticas. El nivel de $\mathrm{pH}$ inicial del zumo de uva tinta $(\sim 3,8)$, adecuado para el desarrollo de levaduras e inadecuado para el desarrollo de bacterias lácticas (BAL) y acéticas (BAC) apoyan esta hipótesis. La desaparición de ácido láctico del medio de fermentación sugiere más su utilización por parte de las levaduras asimiladoras de este ácido, que a un reconsumo por parte de las BAL debido a las altas concentraciones iniciales de azúcares (glucosa y fructosa) en el medio de fermentación.

Descriptores: bebida probiótica, fermentación, kéfir, uvas tintas. 


\section{Abstract}

This study is part of research developed in the area of Food Science, Department of Analytical Chemistry and Food, University of Vigo Ourense Campus, Spain.; whose ultimate goal is to occurring fermented beverages with probiotic properties with kefir grains juice of red and white grapes would thus not valuing vinificables grapes with low commercial value or direct consumption. And obtaining healthy drinks combining ink effects mainly polyphenol grape character with antioxidant kefir and functional benefits. Kinetics main fermentation process cash studied, the effect of change on the fermentation substrate and microbial populations analyzed kefir. The procedure was carried out as follows: the pellet was activated, conducted a sequence of four successive crops. In each one the juice grain was incubated of nonsterile red grape during $24 \mathrm{~h}$. The grain separated and juice fermented by fresh juice was replaced. At 12 hours of incubation and in the juice fermented after $24 \mathrm{~h}$ samples were taken, centrifuged to separate biomass from which the concentration of free cells and CFU of each of the 3 great microbial groups lactic acid bacterium was determined, acetic acid and yeast, and the supernatants were analyzed $\mathrm{pH}$, sugars and metabolites by HPLC. Additionally samples at the beginning and end of each fermentation to determine counts BLA, BAC and LEV were taken. According to the obtained results, it seems logical to use the product fermented obtained for one double purpose. The beverage fermented juice kefir grains inks grapes, could be used as a new alcoholic beverage due to its high ethanol content $(\sim 33 \mathrm{~g} / \mathrm{L})$, after separation of the cells. The probiotic cells obtained with high viability could be used to occurring a food supplement, the potential benefits that their use might have on the health of consumers of the product. Biomass concentrations of free juice obtained during the first two passes, between 1 and $2 \mathrm{~g} / \mathrm{L}$, but in the third pass, a maximum value at about $6 \mathrm{~g} / \mathrm{L}$ is obtained. This rise in the production of free biomass in the third pass, also corresponds with the increased consumption of sugars (glucose and fructose) from the third passage (subculture), possibly because at this stage and kefir grains were adapted to the composition of the fermentation medium again from the average activation. As for the formation of products, catches the eye, compared to whey crops, high yields of ethanol exceeding 4 times, the whey obtained full consumption and lactic acid medium fermentation, the total absence of acetic acid in addition to the production of significant amounts of glycerol from $2 \mathrm{~g} / \mathrm{L}$ in the first pass to about $6 \mathrm{~g} / \mathrm{L}$, in the fourth pass. This suggests an increased activity of the population regarding yeast populations of lactic and acetic bacterium. The initial $\mathrm{pH}$ level of red grape juice ( 3.8), suitable for the growth of yeasts and unsuitable for the development of lactic acid bacterium (LAB) and acetic acid (BAC) support this hypothesis. The disappearance of lactic acid from the fermentation medium suggests further use by the assimilating yeasts of this acid, a reconsumo by $L A B$ due to high initial concentrations of sugars (glucose and fructose) in the fermentation.

Keywords: probiotic drink, fermentation, kefir, red grapes.

\section{Introducción}

El kéfir es una leche fermentada de reconocida fama por sus propiedades nutritivas, producida por un consorcio microbiano denominado grano o gránulo de kéfir [1] y originaria de las montañas del Cáucaso. Se popularizó en Europa y actualmente se comercializa en el sudoeste de Asia, Norteamérica, Japón [2]; Argentina, Taiwán, Portugal, Turquía y Francia [3]. En España fue introducido desde Mallorca, en el Perú se elabora como bebida la llamada chicha de gusano [5].

\section{Características del gránulo de kéfir}

Miden entre $1-3 \mathrm{~cm}$, de forma irregular, blandos, de color blanca-amarillenta y con textura viscosa pero firme [4] y similares a pequeños cogollos de coliflor. Se activan por transferencias diarias en leche fresca, donde crecen en $~ 20$ h. [5, 6]. Están formados por una matriz de polisacárido (kefirano, 9-10\%, compuesto por $1 \mathrm{~mol}$ glucosa/1.14 moles galactosa) y proteínas (3,7-3,8\%), agua (89,9-90,1\%), azúcares $(2,6-2,8 \%)$, grasas $(2,0-2,1 \%)$, sales minerales $(0,7-$ $1,1 \%)[7,8,9,10,11]$.

\section{Propiedades funcionales atribuidas al kéfir}

Contiene además una heterogénea microflora [11] compuesta por bacterias lácticas (Lactobacillus, Lactococcus, Leuconostoc, Streptococcus, Enterococcus), acéticas (Acetobacter) y levaduras (Kluyveromyces, Saccharomyces, Candida) que conviven en simbiosis.

Es Inmunoregulador, antitumoral, antihipertensivo, hipocolesterolémico, cicatrizantes, potenciador de la microbiota intestinal (probiótico, prebiótico) [6]. 


\section{Materiales y Métodos}

\section{Materiales}

Activación del gránulo en leche entera. Inicio:

- Vaso de precipitados de 1L

- Colador de acero inoxidable

- Cuchara

- Agua destilada

- Papel de filtro

- Placa petri

- 3 matraces erlenmeyer de $50 \mathrm{~mL}$

- Probeta de 50 o $100 \mathrm{~mL}$ de plástico

- Tubo falcón (para análisis biológico)

- Tubo de ultracentrífuga pequeños de rotor grande

Toma de muestra y renovación de sustrato

- Vaso de precipitados de $1 \mathrm{~L}$

- Colador de acero inoxidable

- Cuchara

- Agua destilada

- Papel de filtro

- Probeta de 50 o $100 \mathrm{~mL}$ de plástico

- 3 tubos falcon

- 3 vasos de precipitados de $100 \mathrm{~mL}$

- Mosca agitadora

- 3 tubos de ultracentrífuga pequeños de rotor grande

Subcultivos en zumo de uva. Inicio:

- Vaso de precipitados

- Colador de acero inoxidable

- Cuchara

- Agua destilada

- Papel de filtro

- Probeta de 50 o $100 \mathrm{~mL}$ de plástico

- 3 matraces erlenmeyer de $50 \mathrm{~mL}$

- Placa petri

Toma de muestra y renovación del sustrato (fin e inicio de subcultivo)

- Vaso de precipitados de 1L

- Cuchara

- Agua destilada

- Papel de filtro

- Probeta de 50 o $100 \mathrm{~mL}$

- Puntas cortadas de $5 \mathrm{~mL}$

- Pipeta de $5000 \mathrm{uL}$

- 3 tubos de ensayo

- 3 tubos de rosca

- 3 tubos de plástico de tapa verde

\section{Cultivo en placa}

- Tubos eppendorf de $2 \mathrm{~mL}$

- Puntas azules de $1 \mathrm{~mL}$

- Puntas amarillas de 100-200 mL
- Placas petri con tres medios (YCG, MRS y AAB) + plantilla

- Pipetas de 1000 y 100 uL

- Solución salina $(0,8 \%)$

\section{Equipos}

Activación del gránulo en leche

- Balanza de dos decimales

- Incubador orbital

- Ultracentrifuga

\section{Subcultivos en zumo de uva}

- Balanza de dos decimales

- Incubador orbital

- Centrífuga de botes

\section{Condiciones de cultivo}

Unidad experimental

Activación del gránulo en leche

3 matraces erlenmeyer de $50 \mathrm{~mL}$ con su tapón, $3 \mathrm{~g}$ de gránulo y $60 \mathrm{~mL}$ de leche entera.

\section{Subcultivos en zumo de uva}

$1^{\circ}$ subcultivo

Matraz erlenmeyer de $50 \mathrm{~mL}$ con su tapón con 2,5 g de gránulo y $50 \mathrm{~mL}$ de zumo de uva.

\section{Series experimentales}

Activación del gránulo en leche

Fueron tres series experimentales, exactamente iguales.

- Series A: 3 g gránulo + 60mL leche entera agitado a $150 \mathrm{rpm}$ y $20^{\circ} \mathrm{C}$

- Serie B: 3 g gránulo + 60mL leche entera agitado a $150 \mathrm{rpm}$ y $20^{\circ} \mathrm{C}$

- Serie C: 3 g gránulo + 60mL leche entera agitado 150 rpm y $20^{\circ} \mathrm{C}$.

\section{Subcultivos en zumo de uva}

Fueron de tres series experimentales iguales, una por cada serie experimental anterior.

- Serie $A_{1}: 2,5 \mathrm{~g}$ de gránulo $+50 \mathrm{~mL}$ de zumo agitado a $150 \mathrm{rpm}$ y a $20^{\circ} \mathrm{C}$

- Serie $B_{1}: 2.5 \mathrm{~g}$ de gránulo $+50 \mathrm{~mL}$ de zumo agitado a $150 \mathrm{rpm}$ y a $20^{\circ} \mathrm{C}$

- Serie $\mathrm{C}_{1}: 2.5 \mathrm{~g}$ de gránulo $+50 \mathrm{~mL}$ de zumo agitado a $150 \mathrm{rpm}$ y a $20^{\circ} \mathrm{C}$

Procedimiento:

Activación del gránulo de kéfir en leche. Inicio:

- Se descongeló el gránulo de kéfir en agua templada-fría.

- Se colocó el gránulo sobre un vaso de precipitados de $1 \mathrm{~L}$

- Se lavó con agua destilada. 
- Se secó sobre papel de filtro apoyando el colador con el gránulo sobre el papel.

- Se pesó una cantidad de 2,5 g de gránulo en placa petri (uno por cada serie experimental).

- Se depositó sobre un matraz Erlenmeyer de $50 \mathrm{~mL}$ junto con $60 \mathrm{~mL}$ de leche entera medida con probeta.

- Se puso las series experimentales a agitar a 150 rpm y a $20^{\circ} \mathrm{C}$ (temperatura ambiente).

- Se tomó datos de muestra a tiempo 0 de la leche.

\section{Toma de muestra y renovación de la leche}

- Se coló el gránulo sobre un vaso de precipitados de $100 \mathrm{~mL}$.

- El vaso anterior se agitó con una mosca agitadora y se tomaron $1 \mathrm{~mL}$, se vertió en un tubo pequeño de centrífuga de rotor grande.

- Se lavó el gránulo con agua destilada sobre un vaso de precipitados de $1 \mathrm{~L}$ y se secó apoyando el colador sobre papel de filtro.

- A continuación se vertieron $60 \mathrm{~mL}$ de leche medidos con probeta y el gránulo en su interior

- Este paso se realizó cada $24 \mathrm{~h}$.

\section{Toma de muestra al final de la activación}

- Se coló el gránulo sobre un vaso de precipitado de $100 \mathrm{~mL}$.

- Del vaso anterior se toman $1 \mathrm{~mL}$.

- Se lavó el gránulo con agua destilada sobre un vaso de $1 \mathrm{~L}$ y se secó sobre papel de filtro apoyando el colador.

- Se pesaron 0,5 g de gránulo en una placa petri y se echaron sobre una bolsa de stomacher a la que se añadieron $50 \mathrm{~mL}$ se $\mathrm{NaCl}(0,8 \%)$

- Se trituró el contenido y se tomaron $3 \mathrm{~mL}$ del líquido (1 $\mathrm{mL} 3$ veces) y se vertieron sobre un tubo de ensayo.

- Se hizo el procedimiento por duplicado.

- El resto del gránulo se guardó en un bote pírex con leche y se conservó en la nevera.

\section{Inicio en subcultivos en zumo de uva tinta}

- Se llevó 2,5 g de gránulo de cada una de las series experimentales anteriores (se activó en leche) a tres matraces erlenmeyer de $50 \mathrm{~mL}$, uno por cada serie experimental. Previamente el gránulo se lavó, se secó y se pesó.

- Se midió con probeta $50 \mathrm{~mL}$ de zumo de uva y se vertieron en el matraz.

- Se colocó los matraces en el incubador a 150 rpm y a $20 \stackrel{\circ}{\circ}$.

\section{Toma de muestra y renovación del zumo}

Se agitaron el matraz de cada una de las muestras con la mano y se pipeteó la parte superior del mismo.
- Se pipetearon $5 \mathrm{~mL}$ de muestra para un tubo de rosca y otros $5 \mathrm{~mL}$ (se agitó nuevamente) para un tubo de ensayo.

- Se tomó muestra a las $12 \mathrm{~h}$, se añadieron $10 \mathrm{~mL}$ de zumo limpio medidos con probeta y se colocaron otra vez el bote en el incubador.

- Se tomó muestra a las 24 h y se procedió de la siguiente manera:

a. Se pesó el colador sobre la balanza (dentro de campana apagándola).

b. Cada uno de los matraces erlenmeyer se coló reteniendo el gránulo en un vaso pírex de 100 $\mathrm{mL}$.

c. Del vaso anterior se tomaron $1 \mathrm{~mL}$, a un tubo falcón

d. A continuación se secó y se pesó el gránulo (dentro de campana apagándola).

e. Se midieron $50 \mathrm{~mL}$ de zumo con probeta y se vertieron sobren los matraces

f. Por último se colocaron otra vez los matraces en el incubador.

\section{Biomasa gránulo}

- Se cogieron $1 \mathrm{~g}$ de gránulo y se echaron sobre un bote de orina estéril de $50 \mathrm{~mL}$ con $20 \mathrm{~mL}$ de $\mathrm{NaCl}$ $(0,8 \%)$

- Se trituraron mediante ultratúrrax (2 min al 2,2 min en agua a $60{ }^{\circ} \mathrm{C}$ y se repitió el proceso)

- Posteriormente se depositaron $1 \mathrm{~mL}$ en eppendorf de $2 \mathrm{~mL}$ y se centrifugó a $14500 \mathrm{rpm} / 10 \mathrm{~min}$.

- Se tiró el líquido sobrenadante y apliqué el kit de extracción al pellet resultante

\section{Medida de la biomasa libre}

- Se centrifugó los $5 \mathrm{~mL}$ cogidos de cada muestra a los tubos de rosca en la centrífuga de tubos a 4000 $\mathrm{rpm} / 10 \mathrm{~min}$.

- Se guardó el sobrenadante en tubos de rosca verdes y el precipitado se resuspendió en $5 \mathrm{~mL}$ de $\mathrm{NaCl}(0,8 \%)$, se agitó en vórtex y se midió la absorbancia a $700 \mathrm{~nm}$.

\section{Cultivo en placa \\ Gránulo}

- Solamente se hizo al final del cultivo y para cada matraz

- Después que se secó, el gránulo se pesó en una placa petri $1 \mathrm{~g}$ del mismo y se hechó en una bolsa de stomacher con $100 \mathrm{~mL}$ de $\mathrm{NaCl}(0,8 \%)$.

- El contenido anterior de la bolsa se trituró en el stomacher y se tomó $3 \mathrm{~mL}$ con una pipeta de $1 \mathrm{~mL}$ a un tubo de ensayo.

- De los $3 \mathrm{~mL}$ cogidos de la bolsa del stomacher, se tomaron 0,2 y se depositaron sobre un tubo eppendorf de $2 \mathrm{~mL}$ sobre el que previamente se había vertido $1,8 \mathrm{~mL}$ de $\mathrm{NaCl}(0,8 \%)$. 
- Se agitó el tubo para hacer diluciones seriadas en otros tubos eppendorf de $2 \mathrm{~mL}$ con también $1,8 \mathrm{~mL}$ de $\mathrm{NaCl}(0,8 \%)$.

- Se cultivó en placa mediante spots de 10 uL en 3 medios (YGC, MRS y AAB) por duplicado cada uno.

\section{Biomasa libre}

- De los $5 \mathrm{~mL}$ pipeteados de la muestras a los tubos de ensayo, se tomaron 0,2 de cada uno y se depositaron sobre un tubo eppendorf de $2 \mathrm{~mL}$ sobre el que previamente se había vertido $1,8 \mathrm{~mL}$ de $\mathrm{NaCl}(0,8 \%)$.

- Se agitó el tubo y se hizo diluciones seriadas en otros tubos eppendorf de $2 \mathrm{~mL}$ con también 1,8 mL de $\mathrm{NaCl}(0,8 \%)$.

Se cultivó en placa mediante spots de $10 \mathrm{uL}$ en 3 medios (YGC, MRS y AAB) por duplicado cada uno.

\section{Análisis de azúcares, ácidos y alcoholes (HPLC)}

Se descongeló las muestras a cada tiempo congeladas de sobrenadante, se diluyeron x2 y x25 con agua milli-Q cada una y se filtró a través de filtros de acetato de celulosa con tamaño de poro de 0,45 um y se pincharon en el HPLC.

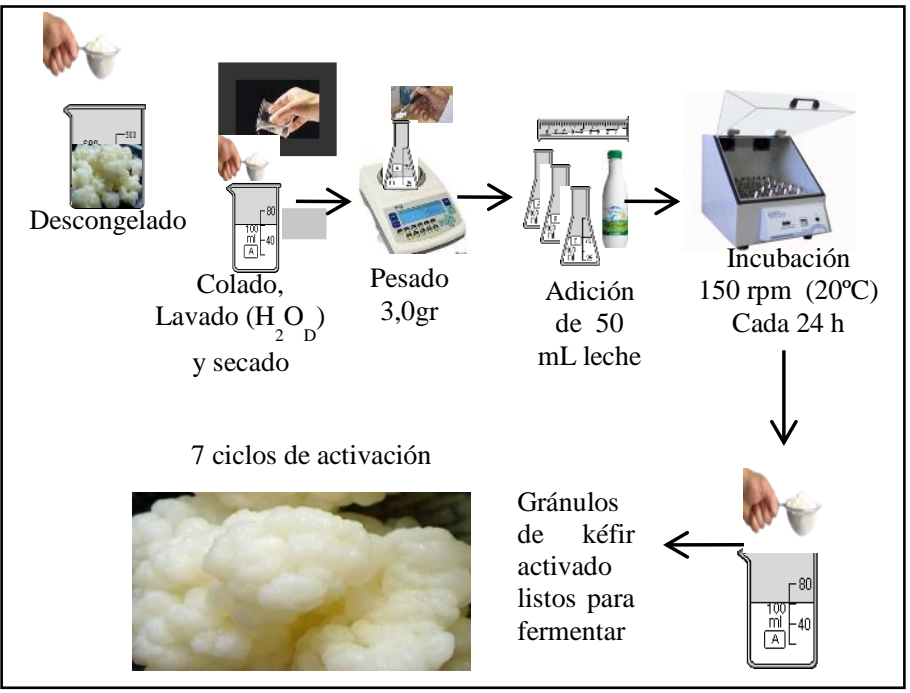

Figura 1: Activación de los gránulos de kéfir

Las figuras 1 y 2 muestran a detalle la secuencia seguida en la activación de gránulos de kéfir y cultivo fermentado en zumo de uvas tintas

Como el gránulo se almacena congelado, es necesario activar los microorganismos antes de realizar la fermentación con zumo de uva.

Para ello, se hicieron una serie de 7 ciclos de activación consistentes en el cultivo del gránulo en su sustrato natural (leche) durante $24 \mathrm{~h}$ cada uno.

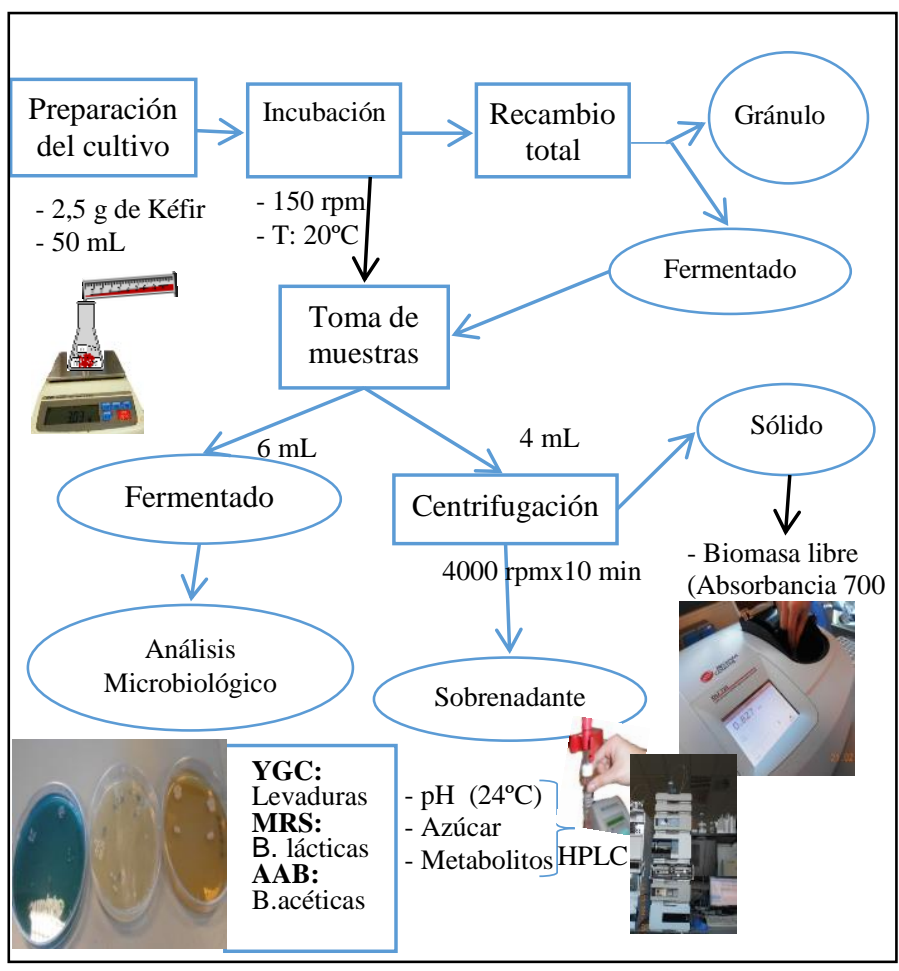

Figura 2: Cultivo fermentado en zumo de uvas tintas

Una vez activado el gránulo, se llevó a cabo una serie de 4 cultivos sucesivos.

En cada uno de ellos se incubó el gránulo en zumo de uva tinta no estéril durante $24 \mathrm{~h}$. Transcurrido este tiempo, se separó el gránulo y se sustituyó el zumo fermentado por zumo fresco.

Toma de muestras: A las 12 horas de incubación y en el zumo fermentado tras $24 \mathrm{~h}$ se tomaron muestras, que se centrifugaron para separar la biomasa (a partir de la cual se determinó la concentración de células libres y las UFC de cada uno de los 3 grandes grupos microbianos: BLA, BAC y LEV), y en los sobrenadantes se analizaron $\mathrm{pH}$, azúcares y metabolitos mediante HPLC.

Adicionalmente se tomaron muestras al inicio y final de cada fermentación (pase) para determinar los conteos de bacterias lácticas acéticas y levaduras. 


\section{Resultados y discusión}

En la presente figura 3, se muestran resultados de la fermentación de zumo de uvas tintas con gránulos de kéfir.

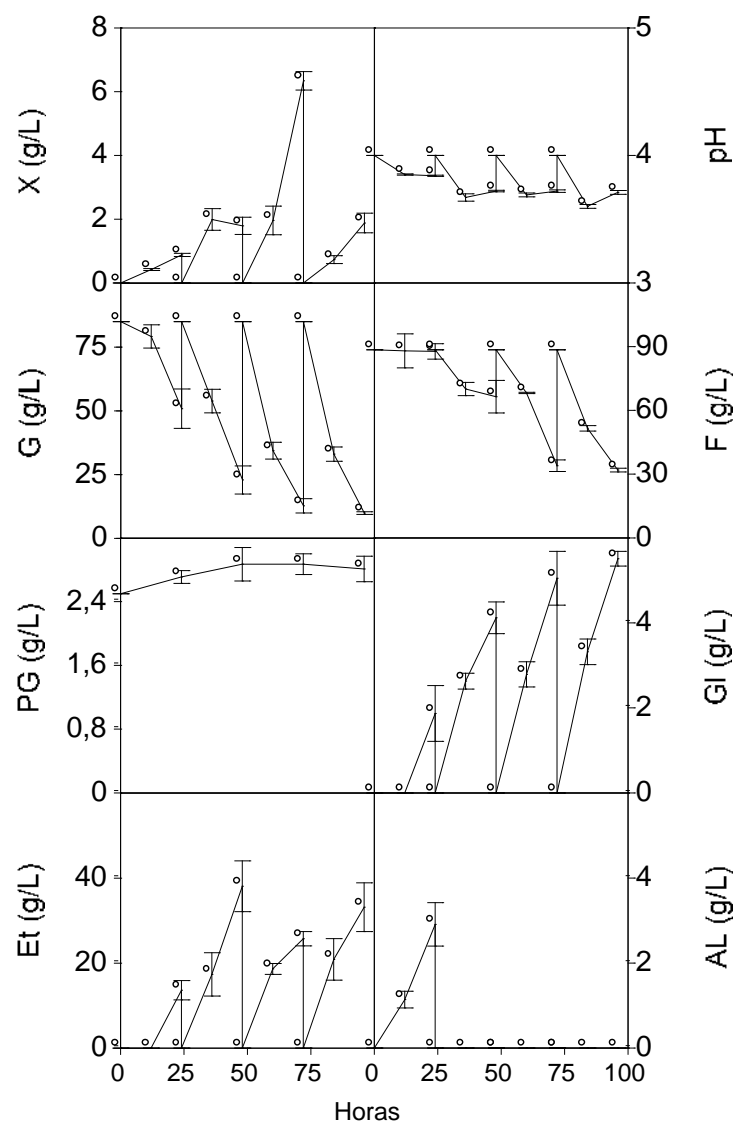

Figura 3: Fermentación de zumo de uvas tintas con gránulos de kéfir.

Como se puede observar, las concentraciones de biomasa libre obtenidas en el zumo durante los dos primeros pases, oscilan entre 1 y $2 \mathrm{~g} / \mathrm{L}$, pero en el tercer pase, se obtiene un valor máximo en torno a los $6 \mathrm{~g} / \mathrm{L}$. Este repunte en la producción de biomasa libre en el tercer pase, se corresponde también con el incremento del consumo de azúcares (glucosa y fructosa) a partir del tercer pase (subcultivo), posiblemente porque en esta etapa ya los gránulos de kéfir estaban adaptados a la composición del nuevo medio de fermentación (zumo de uvas tintas) con respecto al medio de activación (leche entera).
Tabla 1: Niveles promedios obtenidos por cada medio de cultivo, según compuesto ( $g / L$ ) tras el cuarto pase.

\begin{tabular}{|c|c|c|c|}
\hline \multicolumn{2}{|c|}{ Compuesto } & $\begin{array}{l}\text { Cultivos en } \\
\text { suero de } \\
\text { leche }\end{array}$ & $\begin{array}{l}\text { Cultivos en } \\
\text { zumo de uvas } \\
\text { tintas }\end{array}$ \\
\hline \multicolumn{2}{|c|}{ Ácido láctico } & 26,80 & 0,00 \\
\hline \multicolumn{2}{|c|}{ Ácido acético } & 1,40 & 0,00 \\
\hline \multicolumn{2}{|c|}{ Etanol } & 8,30 & 33,2 \\
\hline \multicolumn{2}{|c|}{ Glicerol } & 0,00 & 5,51 \\
\hline \multicolumn{2}{|c|}{ Biomasa libre } & 0,27 & 1,88 \\
\hline & $\begin{array}{l}\text { : biomas } \\
\text { : glucosa } \\
\text { : peso d } \\
\text { : etanol }\end{array}$ & nulo & $\begin{array}{l}\text { : fructosa } \\
\text { : glicerol } \\
\text { : ácido láctico }\end{array}$ \\
\hline \multicolumn{4}{|c|}{$\begin{array}{l}\text { En cuanto a la formación de productos, llam } \\
\text { poderosamente la atención, en comparación con lo } \\
\text { cultivos en suero de leche, las elevada } \\
\text { producciones de etanol (que superan en } 4 \text { veces, la } \\
\text { obtenidas en suero de leche) y el consumo complet } \\
\text { del ácido láctico del medio de fermentación, la totá } \\
\text { ausencia de ácido acético, además de la producció } \\
\text { de cantidades apreciables de glicerol (desde } 2 \mathrm{~g} / \\
\text { en el primer pase hasta aproximadamente } 6 \mathrm{~g} / \mathrm{L} \text {, e } \\
\text { el cuarto pase). }\end{array}$} \\
\hline
\end{tabular}

Todo ello sugiere una mayor actividad de la población levaduriforme con respecto a las poblaciones de bacterias lácticas y acéticas. El nivel de $\mathrm{pH}$ inicial del zumo de uva tinta $(\sim 3,8)$, adecuado para el desarrollo de levaduras e inadecuado para el desarrollo de bacterias lácticas (BAL) y acéticas (BAC) apoyan esta hipótesis.

La desaparición de ácido láctico del medio de fermentación sugiere más su utilización por parte de las levaduras asimiladoras de este ácido, que a un reconsumo por parte de las BAL debido a las altas concentraciones iniciales de azúcares (glucosa y fructosa) en el medio de fermentación. 


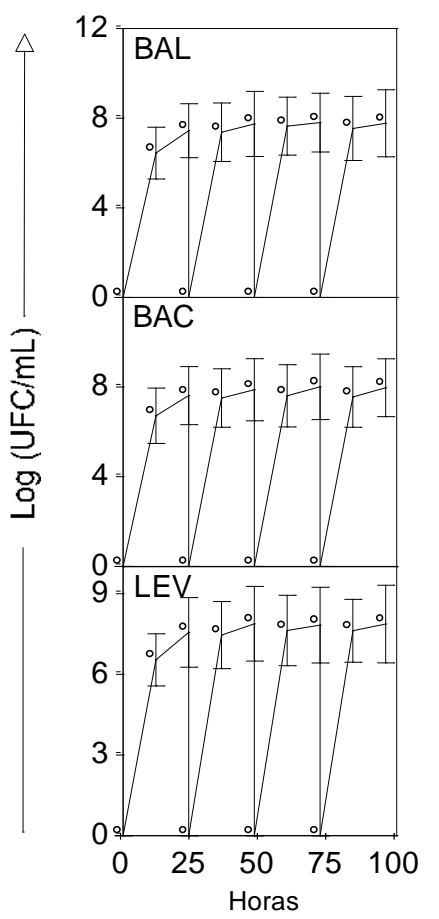

Figura 4: Evolución de las diferentes poblaciones microbianas durante la fermentación

En la figura 4 se muestra la evolución de las poblaciones levaduriformes, BAL y BAC durante el cultivo.

Como se puede observar, aun cuando las producciones de productos (láctico, acético, glicerol y etanol) sugieren lo contrario, las tres poblaciones evolucionaron de forma similar, alcanzándose para cada tipo de microorganismo, concentraciones superiores a $10^{8} \mathrm{UFC} / \mathrm{mL}$ de medio fermentado.

Estas observaciones sugieren que las poblaciones de BAL y BAC crecen a expensas de los azúcares del medio de fermentación y de los productos producidos por la actividad de las levaduras y que éstas se benefician también del metabolismo de las dos primeras.

Sin embargo, conviene recordar que las células en el medio de fermentación, pueden ser el resultado de la liberación continua de células desde el gránulo producto de la agitación, y de la multiplicación de las células liberadas en el zumo.
Tabla 2. Niveles promedios obtenidos por medio de cultivo, según microorganismo (UFC/mL) tras el cuarto pase.

\begin{tabular}{lcc}
\hline Microorganismo & $\begin{array}{c}\text { Cultivos en } \\
\text { suero de } \\
\text { leche }\end{array}$ & $\begin{array}{c}\text { Cultivos en } \\
\text { zumo de uvas } \\
\text { tintas }\end{array}$ \\
\hline BAL $(\mathrm{UFC} / \mathrm{mL})$ & $2,1 \times 10^{4}$ & $5,8 \times 10^{7}$ \\
BAC $(\mathrm{UFC} / \mathrm{mL})$ & $1,5 \times 10^{4}$ & $9,3 \times 10^{7}$ \\
LEV $(\mathrm{UFC} / \mathrm{mL})$ & $1,2 \times 10^{4}$ & $7,3 \times 10^{7}$ \\
\hline
\end{tabular}

BAL : Bacterias ácido lácticas

BAC : Bacterias ácido acéticas

LEV : Levaduras

En cualquier caso, los niveles de células que se obtienen en el zumo son superiores a los referenciados por diferentes investigadores, como mínimos (10 $10^{6} \mathrm{UFC} / \mathrm{mL}$ o $\left.10^{6} \mathrm{UFC} / \mathrm{g}\right)$ para observar efectos probióticos en las entidades hospedadoras.

Por otra parte, las concentraciones de las diferentes especies microbianas (levaduras, BAL y BAC) fueron en el zumo de uvas tintas, de tres órdenes de magnitud superiores a las obtenidas en el suero de leche.

Esto indica, que el zumo constituye un medio de cultivo más adecuado para el desarrollo de las poblaciones presentes en el gránulo de kéfir, debido a la presencia de glucosa y fructosa, que son fuentes de carbono de más fácil asimilación por parte de los microorganismos, que la lactosa del suero de leche.

\section{Conclusiones}

1. Los niveles de productos finales (biomasa libre, etanol, ácidos láctico y acético, glicerol) son diferentes a los obtenidos en suero de leche. Así, los niveles de biomasa libre, etanol y glicerol en zumo de uvas tintas son superiores, pero los niveles de ácidos son inferiores.

2. De acuerdo a los resultados obtenidos, parece lógico utilizar el producto fermentado obtenido para una doble finalidad:

2.1. La bebida obtenida por fermentación de zumo de uvas tintas con gránulos de kéfir, podría ser utilizada como una nueva bebida alcohólica (básicamente un destilado) por su elevado 
contenido en etanol ( $33 \mathrm{~g} / \mathrm{L})$, previa separación de las células.

2.2. Las células probióticas obtenidas, con alta viabilidad podrían ser utilizadas para producir un suplemento alimenticio, por los potenciales beneficios, que su uso podría producir sobre la salud de los consumidores del producto.

\section{Agradecimientos}

A mi asesor de tesis de Posgrado Dr. Nelson Pérez Guerra Profesor Titular de la Universidad de Vigo campus Ourense, Galicia, España; al investigador doctorando Rubén Agregan Pérez; a Sanmiguel Andrés tesista para optar el título de Lic. en Ciencia y Tecnología de los Alimentos; a la Dra. Ana Torrado Agrasar docente catedrática contratada de la Universidad de Vigo co-asesora de mi tesis por su apoyo incondicional. A la Universidad de Vigo por brindarme los laboratorios y me facilitaron todos los medios necesarios para la ejecución del proyecto. Mis infinitas gracias al gobierno peruano Sr. Ollanta Humala Tasso, por medio de la Beca Presidente de la República, que obtuve; un instrumento de política extremadamente poderosa que avanza en la inclusión e igualdad de oportunidades.

\section{Referencias}

[1] E. Simova et al. Lactic acid bacteria and yeasts in kefir grains and kefir made from them. J. Ind. Microbiol. Biotechnol., 28 (1) (2002) 1-6.

[2] V. M. Marshall, W. M. Cole \& B. E. Brooker. Observations on the structure of kefir grains and the distribution of the microflora. J. Appl. Microbiol., 57(3), (1984) 491-497.

[3] E. R. Farnworth. Kefir-a complex probiotic. Food Sci. Technol. Bull., 2(1) (2006) 1-17.

[4] A. G. Abraham \& G. L. de Antoni. Characterization of kefir grains grown in cows milk and in soya milk. J. Dairy Res., 66(02), (1999) 327-333.

[5] M. Blasco. Cómo cura el kéfir. Cómo preparar en casa uno de los yogures más saludables. Editorial RBA Libros. ISBN: 84-7901-(1999) 380-X.

[6] M. Blasco. Kéfir: un yogur para rejuvenecer. (3ed. Ed.) Editorial Barcelona: océano ISBN: 84:7556- (2003) 235-3.

[7] B. T. Hunter. Yogur, kéfir y demás cultivos en leche. Editorial Madrid: Edaf, D.L. (1998).

[8] G. L. Garrote, A. G. Abraham \& G. L. De Antoni. Chemical and microbiological characterization of kefir grains. J. Dairy Res., 68(04), (2001) 639-652.

[9] E. R. Farnworth \& I. Mainville. Kefir: a fermented milk product. Handbook of fermented functional foods. Boca Raton: CRC Press, 200 (2003) 77-111.

[10] H. Yokoi, T. Watanabe, Y. Fujii, T. Mukai, T. Toba \& S. Adachi. Some taxonomical characteristics of encapsulated Lactobacillus sp. KPB-167B isolated from kefir grains and characterization of its extracellular polysaccharide. Int. J. Food Microbiol., 13(4), (1991) 257-264.

[11] J. Zhou, X. Liu, H. Jiang \& M. Dong. Analysis of the microflora in Tibetan kefir grains using denaturing gradient gel electrophoresis. Food Microbiol., 26(8), (2009) 770-775.

\section{Santos Pedraza Guevara}

Egresada, Máster en Ciencia y Tecnología Agroalimentaria de la Universidad de Vigo, Ourense, Galicia, España. Ingeniera Agroindustrial de la Universidad Nacional Toribio Rodríguez de Mendoza de Amazonas.

E-mail:mspg_123@hotmail.com, ingeniera_agroindustrial@hotmail.com 